\title{
Whether Machiavelli Condemns Virtue or Supports It
}

\author{
Yantong Liu
}

\author{
Qingdao Grand International School \\ Yantong Liu Email: 15165231349@163.com
}

\begin{abstract}
Machiavelli (1469-1527) was an Italian politician and historian who was noted for his belief that the means should be used to achieve an end. Machiavellianism has also become synonymous with politics and strategy. Machiavelli was the representative of the emerging bourgeoisie in Italy in the late Middle Ages. He advocated ending the political division of Italy, establishing a strong autocratic monarchy and forming a strong centralized state.
\end{abstract}

Keywords: Machiavellianism, The Prince, virtue, Renaissance

\section{INTRODUCTION}

"The Prince" is a theoretical summary of the "political experiments and drastic changes" in Florence and even the whole Italy during the hundreds of years, as well as Machiavelli's own years of political experience. This paper expounds Machiavelli's theory of autocratic monarchy and monarchy, summarizes the causes of Italy's long war division, and puts forward a plan to realize Italy's unification -- to establish a strong centralized state. Trying to put Dante's idea of unity and the idea of monarchy into practice, as far as possible into the problem of politics, directly to the monarch put forward a variety of implementation methods.

\section{OVERVIEW OF MACHIAVELLI}

Niccolo Machiavelli, Italian political thinker and historian, was born in Florence, Italy in 1469. His ideas are often summarized as Machiavellianism. He was the founder of some important ideas of modern politics, and although he was contradictory and extremely controversial, his ideas were indeed ahead of his time and difficult to understand at the time he lived in. He broke away from the bondage of theology and ethics and opened up a new path of political thought. Today, people say that he is the "father of political science", which also proves his unique and vital position in political thought. In the late 14th century, the movement was known as the "Renaissance" for such prominent figures as Petrarch and Boccaccio and for its humanistic spirit. Machiavelli's incredible almost total rejection of the immediate intellectual legacy of his time, and his teachings continued to influence the Western world for nearly 500 years after his death, leading Leo Strauss to remark: "By the prince to a prince, the discourses on the levy to private citizens, he will become a pioneer, signal in the coming future, a political scientist will put himself about freedom and democracy of the whole thesis, a successor to the President Eisenhower, his paper about communism, a successor to the bulganin."As a giant in the history of political science, what is Machiavelli's own political views? Is he a monarchist or a republican? This question has been one of the central debates among Machiavelli researchers throughout the ages.

\section{MACHIAVELLI'S EXPERIENCES AND BASIC IDEAS}

When we think of Machiavelli, the first thing that comes to mind is his The Prince, a book that teaches us how to play politics by Machiavelli. Hence the word Machiavellianism to describe the political manipulation of other people through power, stratagem, etc. Machiavelli was born into an aristocratic family that had once been prominent but had fallen into poverty. However, his father Bernardo Machiavelli's interest in learning, as well as the library and academic atmosphere of his home, contributed greatly to his success. It can be said that the family influence played an important part in his development. He grew up in Florence, which was full of political fights and bloody storms. After spending an ordinary childhood with their own knowledge and ability to have later as. Later in his life in seclusion, he wrote one of the most influential works in world political history, "The Prince," which was dedicated to the Medici family and he wanted to be appreciated by them. Much of machiavellianism and his knowledge came from this book. One of them was the idea that the monarch should not be bound by moral principles, but should only be 
judged by his effectiveness, whether or not he was gentle or cruel. In Shakespeare's works, Machiavelli became a sinister, deceitful, duplicity, treacherous, The Prince is referred to as "evil" of the bible, this book is also considered a classic by European monarchs and one of the most influential works in human history,along with the Bible and Das Kapital, in western public opinion. A lot of people who read The Prince think that Machiavelli is a totalitarian and authoritarian, and they think that he's going to do whatever it takes to get what he wants, but the paradox is that what he says in "the Discourses" is at odds with some of the core ideas that "The Prince" makes. But is "The Prince" really a denunciation of morality? And otherwise.

\section{MACHIAVELLI'S CONCRETE IDEAS}

From the perspective of the contribution of The Prince to political science, there are several points: First, Machiavelli distinguished politics from ethics and put forward the non-moral political view; Second, he separated politics from religion, put forward the antireligious view of the state, cut off the connection between God and secular power; Third, he put forward the concept of power for politics, that is, the monarch monopolizes power and maintains his rule with excellent army and perfect laws.

Machiavelli received praise and criticism mainly focused on the politics and morality he advocated. In his famous theory of the Lion and the fox, he proposed that man has two methods of fighting: one is the use of law, which is the rational behavior peculiar to man, and the other is the use of force, which is the animal behavior. Under the social conditions of that time, people were often powerless to only use rational behavior, so the monarch needed to know how to fight with the behavior of beasts. The prince should imitate both the lion and the fox, both brave as the lion to frighten the Wolf and cunning as the fox to avoid the trap. He needs to be fierce as a lion and cunning as a fox, for a lion cannot defend himself against a trap, and a fox against a wolf.This is what it says in the prince: "A prince, therefore, being compelled knowingly to adopt the beast, ought to choose the fox and the lion; because the lion cannot defend himself against snares and the fox cannot defend himself against wolves. Therefore, it is necessary to be a fox to discover the snares and a lion to terrify the wolves. Those who rely simply on the lion do not understand what they are about."[1] He even put forward that the monarch should be a great liar and hypocrite. When the promise he keeps is not good for himself, a wise monarch cannot and should keep his promise. The monarch should learn to disguise himself and put on the appearance of morality in order to gain people's love.

Although he taught you to put your own interests first, that's normal. But from the point of view of human nature, Machiavelli's moral view is not immune to criticism even today. What we should do is not to criticize his views, but to dispassionately analyze why he came up with such moral values. As he said in The Prince: "For this reason a prince ought to take care that he never lets anything slip from his lips that is not replete with the above-named five qualities, that he may appear to him who sees and hears him altogether merciful, faithful, humane, upright, and religious."[2]

I think it is mainly based on his understanding of "human evil". Machiavelli believed that human nature was evil, and this was the starting point of all his thoughts. In The Prince, he shows this realization many times: "Because this is to be asserted in general of men, that they are ungrateful, fickle, false, cowardly, covetous, and as long as you succeed they are yours entirely; they will offer you their blood, property, life, and children, as is said above, when the need is far distant; but when it approaches they turn against you. "If men were entirely good this precept (that a prince should have the strength of a lion and the cunning of a fox) would not hold, but because they are bad, and will not keep faith with you, you too are not bound to observe it with them." [3]Then, about civic virtue and corruption. The "virtue" Machiavelli mentioned is different from the character of people in the general sense, but refers to a series of abilities that everyone needs to possess as a citizen, which can make citizens consciously serve the public interest, consciously defend the freedom of the republic, and ensure the strength of the republic and individual freedom. However, Machiavelli is pessimistic about the continuance of virtue. Because of the aforementioned "evil nature", people will gradually lose their "virtue" and endanger the republic -- this is the "corruption" that runs through Discourses on Livy. For the people, "corruption" is the inevitable result of republican virtue; For a monarch, corruption is an inevitable consequence of his nature. Corruption, in short, is the failure to recognize that one's freedom depends on virtue and public service: if we wish to enjoy as much freedom as possible, we must first be virtuous citizens, putting the common good above our own or group interests.

Second, Machiavelli lived in a divided Italy, as described in The Prince: "And if, as I said, it was necessary that the people of Israel should be captive so as to make manifest the ability of Moses; that the Persians should be oppressed by the Medes so as to discover the greatness of the soul of Cyrus; and that the Athenians should be dispersed to illustrate the capabilities of Theseus: then at the present time, in order to discover the virtue of an Italian spirit, it was necessary that Italy should be reduced to the extremity that she is now in, that she should be more enslaved than the Hebrews, more oppressed than the Persians, more scattered than the Athenians; without head, without order, beaten, despoiled, torn, overrun; and to have endured every kind of desolation." [4]What he yearned for was a powerful monarch to establish a strong and unified state, and in 
order to achieve this goal, in order to achieve unity, he could do anything, and only when the country is unified can the people be happy. In his other work "the Discourses" we can see that Machiavelli is yearning for a democratic republic, but in the social conditions of that time is not with such a foundation, so he proposed a radical monarchy.

\section{MACHIAVELLI'S MORALITY}

People have been puzzled by the apparent opposition of Machiavelli's views expressed in The Prince and On Livy. From the point of the establishment of autocrats, there is no contradiction between the two. Autocracy is needed for the establishment of a unified state, while republic is needed for the maintenance of a stable state. Despotism is what a nation needs when it is in danger, a republic when it is in security. In The Discourses, Machiavelli juxtises republicanism and despotism in a way that undermines the age-old notion that The Discourses is a wholesome republican work in opposition to the evil, despotic Prince. "The Discourses" has more "monarchist" tendency, the integration of absolutism and republicanism, more criticism of the classical era and Christian morality, so it is far more brilliant than the ageold stereotype. Personally, I think Machiavelli was moral, and a great moral, because he built this morality on the basis of a nation, so we cannot and should not consider him in terms of human nature. His ultimate goal is to protect his people and strengthen his country.It is normal and necessary not to violate human nature should be. He said in the Prince, quoting Petrarch, "For the old Roman valour is not dead, Nor in th' Italians' brests extinguished."[5] The old Roman valour he was referring to was the courage to fight to unite Italy.An honest man is not fit to be king, just as our laws respect humanity and put people first. The king's policy must be accepted by the people. Machiavelli's Kings were not good, but they did what a king should do. It can be seen as an interpretation of human nature or a case textbook on how to use politics. Machiavelli believed that human beings were inherently evil, but that doesn't mean what kind of moral system he thinks should be built. During the Warring States period in ancient China, the famous thinker Xunzi also put forward the theory of "evil nature". Under the influence of his thought, The legalism advocated by Han Feizi provided the ideological basis for the unification of China by The First Emperor of Qin. Machiavelli believes that individuals are unable to deal with their desires and their ability to control them, and often their pursuit of desires far exceeds their ability to satisfy them. The antagonism between the two makes people greedy, selfish and cowardly. At the same time, Machiavelli believes that this contradiction is rooted in the depths of human heart. Based on this phenomenon, he advised for the monarch, put forward the use of people's internal, congenital contradictions, as an important means to achieve national unity and prosperity. This constitutes the starting point for all kinds of extraordinary means that the monarch applied to the state, and it is also a watershed for Machiavelli to completely distinguish "moral" from "political".

Machiavelli believed that individuals in a society have a tendency to "evil" in the face of various complex environments, and this natural tendency cannot be overcome by the individuals themselves. Although Machiavelli held these views, it was an argument for him to give advice to the rulers in order to make the country rich and powerful. The essence of The Prince is a political work, is Machiavelli for get the Medici appreciation on the political policy, for its purpose is not to criticize or interpretation of human nature and morality, but the contradictions in the human nature as the breakthrough point, turned them into a tool that can be used on politics, and to separate morality completely from politics. It makes his views seem totally unscrupulous and without moral boundaries. But The Prince is also his advice to the ruler, about how to strengthen and unify the country, itself can be said to be for the country, based on a high moral position and starting point. Machiavelli's numerous contradictions cannot be defended in the same way as the Prince: if the latter is a work dedicated to a prince and has to be mixed with flattery and pomp, then the former should be a work from the heart, as it says, and should express his true thoughts. Yet he himself more or less indicated the means by which all these contradictions could not be made a problem: it was teleology through and through. That is, all means are ok, and all regimes are ok, so long as they have good results.

Machiavelli's theory of "the evil of human nature" and his "criticism" of virtue have their own presuppositions, they need to be established in specific social conditions, which is the conditional assumption he made when he offered advice to the monarch under complex social conditions. He hoped his book be adopted and appreciated by rulers, at the same time, he considered about his country which is in danger. Even if he is regarded as an unscrupulous villain, it cannot be denied that it is unreasonable to measure politics by morality. A good man with high morals may not be a good ruler, nor can he save Italy from the crisis. It is meaningless to evaluate politics from the point of view of morality. Machiavelli's advice to the prince was related to the security of the country at the same time, he was really for the sake of his country, which is a great moral which should be praised.

\section{CONCLUSION}

Machiavelli and his works are full and threedimensional. Behind the cold political discourse lies his deep insight into human nature and deep affection for the masses. Machiavelli's work is a curious blend of his Florentine political experience, which gives Machiavelli deep political insight, and the Renaissance spirit, which 
cuts through the cold politics to reveal a touch of tenderness and hope. In the Prince, Machiavelli gave the world the image of a "Machiavellian". He taught the monarch how to do whatever it takes to get what he wants, and how to openly and boldly show the world the astonishing techniques of politics and intrigue. This is similar to the "shu" technique in Chinese pre-Qin legalists. What about Machiavelli's view of law? What are his views on institutions and regimes? Many of his critics saw the Prince as a textbook for dictators and schemers, but what surprised the readers was that in his earlier, even more representative, Treatise on Livy, he devoted his laudatory words to the Roman Republic, to the republic. Many believe that the republic is Machiavelli's preferred form of government, and that "The Prince" is a work offered to the monarch in a quest for status, perhaps even an irony.

\section{ACKNOWLEDGMENTS}

The author would like to thank Prof.Hankins, who provides significant academic assistance. The author also wishes to thank the teachers from Qingdao Grand international school who gives many valuable suggestions for the writing of this article.

\section{REFERENCES}

[1] Niccolo Machiavelli, The Prince,Liaoning People's Publishing House, University Of Chicago Press, 2014, chapter XVIII

[2] Niccolo Machiavelli, The Prince,Liaoning People's Publishing House, University Of Chicago Press, 2014, chapter XVIII

[3] Niccolo Machiavelli, The Prince,Liaoning People's Publishing House, University Of Chicago Press, 2014, chapter XVII

[4] Niccolo Machiavelli, The Prince,Liaoning People's Publishing House, University Of Chicago Press, 2014, chapter XXVI

[5] Niccolo Machiavelli, The Prince,Liaoning People's Publishing House, University Of Chicago Press, 2014, chapter XXVI 